\title{
Institutional Effectiveness Assessment Based on the Quality of Institutional Economic Structure in the Current Context
}

\author{
Natalya Pavlovna Vinogradova \\ Kostanaysk branch of Chelyabinsk State University, Kostanay, Kazakhstan \\ E-mail: vin.natalya@gmail.com
}

\section{Doi:10.5901/mjss.2015.v6n5s4p576}

\begin{abstract}
Institutional effectiveness is an integral condition of economic performance of any state. The article examines three clusters of countries according to the level of institutional effectiveness. Influence priorities of institutional structure quality on the level of institutional economic effectiveness are determined for each cluster. The model of institutional economic effectiveness is discussed for each cluster of countries. The model enables to differentiate institutional economic structure of countries depending on the level of institutional effectiveness. The article suggests a number of transformations aimed at increasing institutional economy.
\end{abstract}

Keywords: institutions, institutional effectiveness, economic growth, quality of institutional structure, economy, institutional theory.

\section{Introduction}

Within an economic system institutions change or lose their qualitative characteristics in the course of some time. Some institutions advance by more rapid leaps, transforming or generating new economic management rules, other ones lose their operational relevance. This process represents institutional amendments, resulting in formation of a definite institutional structure in the economy. Optimal institutional structure provides effectiveness of the economy. Dysfunctional institutional environment, characterized by the loss of qualitative characteristics of the institutions, determines effectiveness underperformance, provoking economic recess. Decline in the qualitative characteristics of institutional structure of the national economy may have critical consequences with regard to the sustainable performance of institutional environment.

\section{Literature Review}

Analysis of the results of investigations by the leading scholars indicates the level of theoretical development of institutional economic effectiveness subject. The general concept of 'effectiveness' is one of the basic definitions of the economic theory (Volchik and Oganesyan, 2014). Within the paradigm of institutional theory the institutionalists connect this economic category with the concept of the institutions. An institution is understood as the rules of conduct and regulatory principles, establishing or prohibiting definite ways of proceeding in the economy (Veblen, 2011; Coase, 2001; Inshakov, 2003). In the numerous scientific papers dealing with institutional and evolutional economy the issue of the institutional effectiveness definition is studied in detail (Dementiev and Nureev, 2011; Kozyrev, 2014; Beck and Laeven, 2006). From this viewpoint the position of $M$. Rotbard seems interesting; according to the scholar, it is reasonable to use the concept of justice relating to the institutional effectiveness (Rotbard, 1979). In general, the concept of effectiveness is used within the interdisciplinary approach to describe social phenomena, in particular as applicable to the institutions as well (Nureev, 2000; Pohoaţă, 2015; Marin and Bjorkland, 2015; Siddiqui and Masood, 2009; Sukharev, 2007). Effectiveness of the institutions is understood as a process of production cost and transaction expenses minimization, as well as the ability to produce economic growth (North, 1997).

The Pareto principle is based on the fact that institutional effectiveness is achieved when no other additional actions fail to improve anybody's wealth without decreasing the wealth of other individuals (Zaslavskaya, 2004; Cleaver, 2015). Its shortcoming is practical inapplicability. The problem of institutional effectiveness according to Pareto was solved by the idea of effectiveness in the theory of economic mechanisms.

The principle of the Kaldor-Hicks efficiency compensation criterion (Kaldor, 1939; Hicks, 2004) consists in the fact that a public goal may be differentiated according to context of the research (Maskin, 2013; Shapkin, 2011). 
Since these approaches were based on the qualitative characteristics of the institutional effectiveness assessment, institutional theory was replenished with the works relating to the quantitative assessment of the institutional performance in the economics. The concepts of welfare indicator and adaptive effectiveness of Douglas North became the most famous scientific achievement. The basis of this scientific theory is presented by the substantiation of the approach to the assessment of institutional economic effectiveness by measuring values having price nature (North, 1997).

The theory of growth became widespread in the scientific circles. In compliance with this theory the quality of the institutions predetermines the rates of economic development in the country. Numerous studies confirm this idea demonstrating that the developed democracy, efficient property rights or fair justice system are the prerequisites for the higher rates of the economic growth (Baum and Lake, 2003; Lane and Rohner, 2014; Siddiqui and Masood, 2009; Fioretos and Falleti, 2015).

Also within the institutional effectiveness theory multiple fundamental works on the non-effectiveness of the institutions were formed. Special attention is deserved by the works on the dysfunction (Sukharev, 2007).

The presented concepts have made an undisputable contribution into the theory of institutional economic effectiveness. At the same time, relying on the scientific achievements and accumulated practical experience, the conceptual aspect still retain the debatable nature of the problem solution in the issues under investigation. In particular, the issues concerning provision of institutional effectiveness based on qualitative proportions of institutional economic structure remain unsolved. The study of these issues may serve a basis for improving the theory of institutional effectiveness and the institutional theory as a whole.

\section{Research Methodology}

The methods of multivariate statistical analysis were applied in the course of investigation.

\subsection{Cluster analysis method}

The clusters of countries were formed according to the level of institutional effectiveness by the hierarchical clustering method based on the least value of Euclidian distance. The World Economic Forum quality rating of institutional structure components of the studied 144 countries with different level of economic development became the basis of clusterization. Adequacy of the countries' clusterization results are proved by the Fisher test and the required level $p$-error.

\subsection{Correlation and regression analysis method}

Using paired correlation coefficient, there was established the density of connection between the rating of institutional economic structure quality for the clusters of countries and the general level of institutional economic effectiveness. Paired correlation coefficients served a basis for determining the priorities of influence of the institutional economic structure quality on the level of institutional effectiveness. The least square method enabled to determine the quantitative level of influence priority ranking for the institutional structure quality on the performance of institutional effectiveness. The influence priority ranking is presented as a regression model.

\section{Findings}

As of 2014 the World Economic Forum distinguished ten countries of 144 with the highest level of institutional effectiveness (see Figure 1). New Zealand ranks first in the rating of the world countries by the global competitiveness index in terms of the effectiveness of the economic institutions. Institutional effectiveness of the national economy, expressed in the assessment of the level of the country's property rights protection, within the World Economic Forum methodology was assessed to make 6.09 grades of 7 maximum possible ones (Schwab, 2014). 


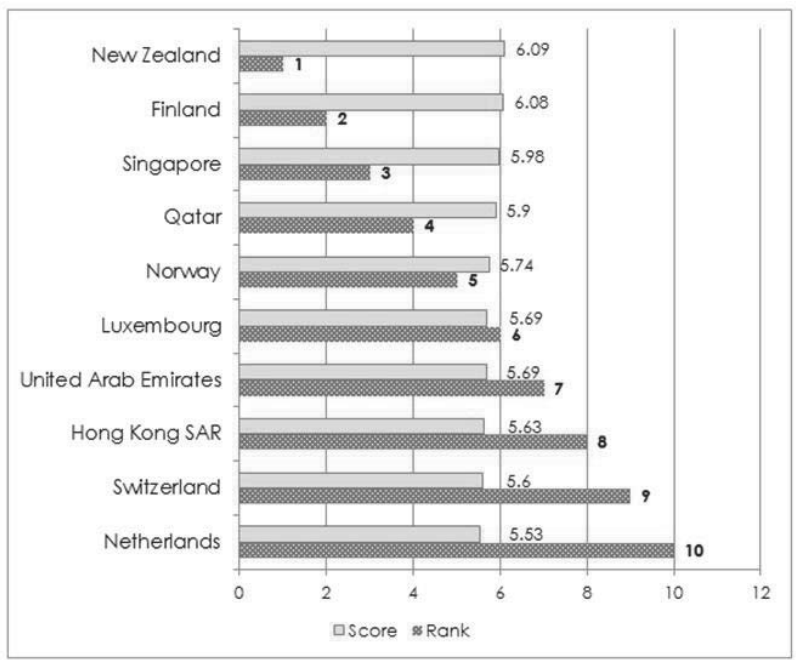

$\left({ }^{*}\right.$ Compiled by the author according to (Schwab, 2014))

Figure 1. Rating of the countries with the highest level of institutional effectiveness as of 2014

It should be noted that most countries with the highest level of institutional effectiveness are also the leaders in terms of global competitiveness criterion. National economies of such countries, as Switzerland, Hong Kong SAR, Singapore, Finland, New Zealand and Netherlands form Top 10 countries with institutional environment able to provide maximum stable rates of economic growth and their sustainability on a mid-term horizon (Figure 2).

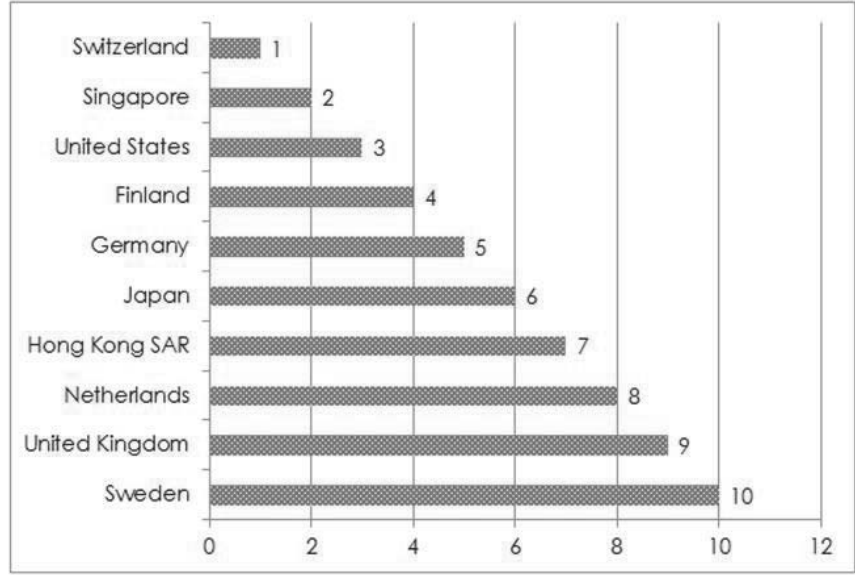

$\left({ }^{*}\right.$ Compiled by the author according to (Schwab, 2014))

Figure 2. Rating of Top 10 world countries according to global competitiveness index in 2014.

As indicated by the statistical data, over the recent five years the most competitive global economies were characterized by the fairly stable dynamics of GDP growth. Over the period under consideration the national economy growth made approximately $107 \%$ on average for ten countries with the highest level of institutional effectiveness (Figure 3). 


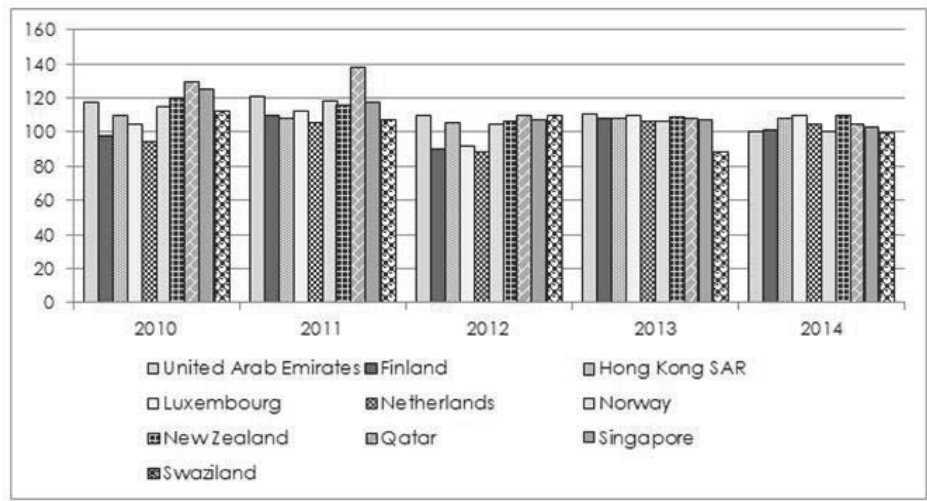

( ${ }^{*}$ Compiled by the author according to World Bank Group, 2014)

Figure 3. GDP growth rate dynamics for Top 10countries with the highest level of institutional effectiveness, \%

The institutional concept implies that institutions determine the development type and level for the social and economic system of any state (Kooij et al., 2015; Olson, 2000). The institution performance in the conditions of the market economy shall satisfy the fundamental criterion - effectiveness in the context of social and economic development programs (Yefimov, 2013). Dominance of a certain economic structure of the institutions stipulates economic liberalization and economic growth or is a factor of their rejection (Lawson, 2006; Williamson, 1992).

Within the scope of the scientific research an attempt was made to define the optimal institutional structure quality of the national economies of the global countries providing a high level of institutional effectiveness, and hence, sustainable economic development of the state.

The institutional indicator components of the Global Competitiveness Index were used as a subject of investigation (Schwab, 2014). The institutional effectiveness indicator reflects the legal and administrative structure, within which individuals, businesses and governments interact to create the conditions for the welfare growth (Kuzmenko, 2008; Schwab, 2014).

Qualitative rating figures of the Global Competitiveness Index for 144countries of the world as of 2014 concerning the quality of institutional economic structure served as a statistical basis of the analysis, cluster and correlationregression analysis formed the methodology of the research (Schwab, 2015). STATISTICA 8.0. package was applied to practically test the multivariate statistical analysis.

The cluster analysis technology implies formation of an aggregate of clusterization objects, minimizing the size of Euclidian distance between the cluster center and its components:

$d_{i j}=\sqrt{\sum_{k}^{n}\left(x_{i k}-x_{j k}\right)^{2}}$,

where $d_{i j}$ - distance from the i-th object to the $\mathrm{j}$-th cluster center;

$x_{i k}-\mathrm{k}$-th coordinate of the i-th object;

$x_{j k}$ - k-th coordinate of the $j$-th cluster center (Artamonov, 2010).

As a result of the carried out mathematical transformations, three groups of the clusters of countries were formed according to the level of their institutional development or effective functioning of economic institutions (Table 1) (Annex 1). Average values of institutional effectiveness ratings by the clusters are given in table 4.

Adequacy and validity of the results obtained in the process countries clusterization according to the indicators of institutional effectiveness are confirmed by the dispersion analysis figures. By means of STATISTICA 8.0. software product it was determined that for each indicator intergroup dispersion exceeds the within-group variation. The value of $\mathrm{F}$ criterion $(F)$ is higher than the tabulated one (the tabulated value of the Fisher test for the degrees of freedom (df) 2; 141 with the analysis validity level $95 \%$ makes 3.06 . Level of $p$-error does not exceed 0.05 . Statistical characteristics indicate the significance and adequacy of the formed clusters according to the level of institutional effectiveness. 
Table 1 - Clusters of countries with different levels of institutional economic effectiveness

\begin{tabular}{|c|c|c|c|c|c|}
\hline \multicolumn{6}{|c|}{ Levels of institutional economic effectiveness } \\
\hline \multicolumn{2}{|r|}{ high } & \multicolumn{2}{|r|}{ middle } & \multicolumn{2}{|r|}{ low } \\
\hline No & Cluster of countries & No & Cluster of countries & No & Cluster of countries \\
\hline 1 & Australia & 1 & Armenia & 1 & Albania \\
\hline 2 & Austria & 2 & Azerbaijan & 2 & Algeria \\
\hline 3 & Belgium & 3 & Bahrain & 3 & Angola \\
\hline 4 & Canada & 4 & Barbados & 4 & Argentina \\
\hline 5 & Chine & 5 & Bhutan & 5 & Bangladesh \\
\hline 6 & Denmark & 6 & Botswana & 6 & Bolivia \\
\hline 7 & Estonia & 7 & Cape Verde & 7 & Brazil \\
\hline 8 & Finland & 8 & China & 8 & Bulgaria \\
\hline 9 & Germany & 9 & Costa Rica & 9 & Burkina Faso \\
\hline 10 & Hong Kong SAR & 10 & Cyprus & 10 & Burundi \\
\hline 11 & Iceland & 11 & Czech Republic & 11 & Cambodia \\
\hline 12 & Ireland & 12 & France & 12 & Cameroon \\
\hline 13 & Japan & 13 & Gambia, The & 13 & Chad \\
\hline 14 & Luxembourg & 14 & Georgia & 14 & Colombia \\
\hline 15 & Malaysia & 15 & Ghana & 15 & Côte d'Ivoire \\
\hline 16 & Netherlands & 16 & Greece & 16 & Croatia \\
\hline 17 & New Zealand & 17 & Hungary & 17 & Dominican Republic \\
\hline 18 & Norway & 18 & India & 18 & Egypt \\
\hline 19 & Oman & 19 & Indonesia & 19 & El Salvador \\
\hline 20 & Qatar & 20 & Israel & 20 & Ethiopia \\
\hline 21 & Rwanda & 21 & Jordan & 21 & Gabon \\
\hline 22 & Saudi Arabia & 22 & Kazakhstan & 22 & Guatemala \\
\hline 23 & Singapore & 23 & Kenya & 23 & Guinea \\
\hline 24 & Sweden & 24 & Korea, Rep. & 24 & Guyana \\
\hline 25 & Switzerland & 25 & Kuwait & 25 & Haiti \\
\hline 26 & Taiwan, China & 26 & Lao PDR & 26 & Honduras \\
\hline 27 & United Arab Emirates & 27 & Latvia & 27 & Iran, Islamic Rep. \\
\hline 28 & United Kingdom & 28 & Lesotho & 28 & Italy \\
\hline 29 & United States & 29 & Lithuania & 29 & Jamaica \\
\hline & & 30 & Macedonia, FYR & 30 & Kyrgyz Republic \\
\hline & & 31 & Malawi & 31 & Lebanon \\
\hline & & 32 & Malta & 32 & Libya \\
\hline & & 33 & Mauritius & 33 & Madagascar \\
\hline & & 34 & Montenegro & 34 & Mali \\
\hline & & 35 & Morocco & 35 & Mauritania \\
\hline & & 36 & Namibia & 36 & Mexico \\
\hline & & 37 & Panama & 37 & Moldova \\
\hline & & 38 & Philippines & 38 & Mongolia \\
\hline & & 39 & Poland & 39 & Mozambique \\
\hline & & 40 & Puerto Rico & 40 & Myanmar \\
\hline & & 41 & Senegal & 41 & Nepal \\
\hline & & 42 & Seychelles & 42 & Nicaragua \\
\hline & & 43 & Slovenia & 43 & Nigeria \\
\hline & & 44 & South Africa & 44 & Pakistan \\
\hline & & 45 & Spain & 45 & Paraguay \\
\hline & & 46 & Sri Lanka & 46 & Peru \\
\hline & & 47 & Swaziland & 47 & Portugal \\
\hline & & 48 & Tajikistan & 48 & Romania \\
\hline & & 49 & Thailand & 49 & Russian Federation \\
\hline & & 50 & Tunisia & 50 & Serbia \\
\hline & & 51 & Turkey & 51 & Sierra Leone \\
\hline & & 52 & Uruguay & 52 & Slovak Republic \\
\hline
\end{tabular}




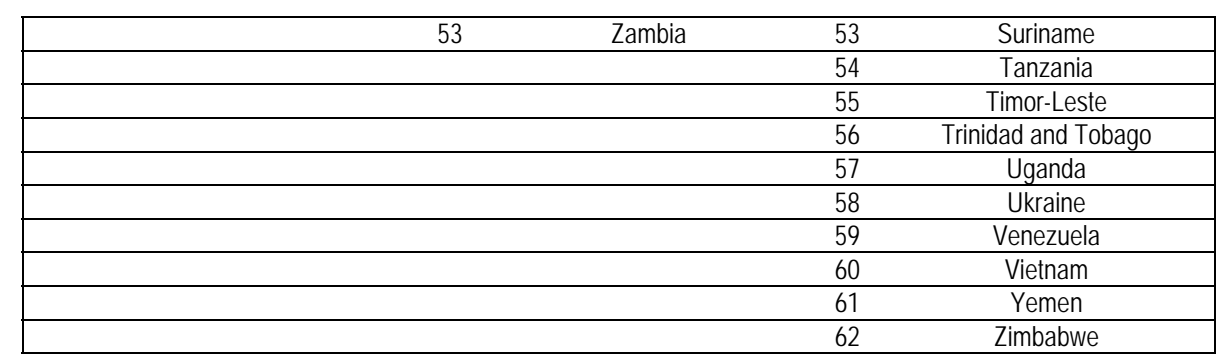

$\left({ }^{*}\right.$ Compiled by the author according to (Schwab, 2014))

Based on the clusterization of countries according to the level of the institutional structure effectiveness, it is possible to state the following. The first cluster includes the countries with average ratings of institutional economic effectiveness assessed within the range of $\min =4.7, \max =6.5$. The second cluster is formed by the groups of countries ranging within $\min =3.1, \max =4.6$. In the third cluster the countries characterized by the least level effective performance of the economic institutions are grouped: $\min =2.3, \max =4.5$ (Table 2).

In order to determine the influence priority ranking of institutional economic structure quality by the clusters of countries using formula 2 (Artamonov, 2010) paired correlation coefficients have been calculated in the research (Annex 2).

$r_{y x}=\frac{\overline{x y}-\bar{x} \cdot \bar{y}}{\sigma_{x} \cdot \sigma_{y}}$,

where $\overline{x y}$ - mean product of $x$ and $y$ attributes;

$\bar{x}, \bar{y}-$ mean value of $x$ and $y$ attributes, respectively;

$\sigma_{x}$ - mean-square deviation of $x$ attribute (formula 3);

$\sigma_{y}$ - mean-square deviation of $y$ attribute (formula 4) (Artamonov, 2010);

$\sigma_{x}=\sqrt{\frac{\sum(x-\bar{x})^{2}}{n}}$

$\sigma_{y}=\sqrt{\frac{\sum(y-\bar{y})^{2}}{n}}$

Table 2. Average value of institutional economic effectiveness rating by the clusters of countries

\begin{tabular}{|lccc|}
\hline \multirow{2}{*}{ Parameter } & Cluster 1 & Cluster 2 & Cluster 3 \\
\cline { 2 - 4 } & \multicolumn{3}{c|}{ Average rating } \\
\hline Property rights & 5.7 & 4.4 & 3.3 \\
\hline Intellectual property protection & 5.5 & 4.0 & 2.9 \\
\hline Diversion of public funds & 5.5 & 3.6 & 2.5 \\
\hline Public trust in politicians & 4.8 & 3.1 & 2.3 \\
\hline Irregular payments and bribes & 5.9 & 4.3 & 3.1 \\
\hline Judicial independence & 5.8 & 4.1 & 2.8 \\
\hline Favoritism in decisions of government officials & 4.9 & 3.2 & 2.5 \\
\hline Wastefulness of government spending & 4.9 & 3.3 & 2.5 \\
\hline Burden of government regulation & 4.8 & 3.5 & 3.1 \\
\hline Effectiveness of legal framework in setting disputes & 5.2 & 3.9 & 3.0 \\
\hline Effectiveness of legal framework in challenging regs & 4.7 & 3.5 & 2.8 \\
\hline Transparency of government policymaking & 5.1 & 4.1 & 3.5 \\
\hline Business costs of terrorism & 5.8 & 4.6 & 4.5 \\
\hline Business costs of crime and violence & 5.6 & 4.6 & 3.6 \\
\hline Organized crime & 6.0 & 4.6 & 4.0 \\
\hline Reliability of police services & 5.9 & 4.4 & 3.3 \\
\hline Ethical behavior of firms & 5.6 & 4.2 & 3.5 \\
\hline Strength of auditing and reporting standards & 5.7 & 4.6 & 4.0 \\
\hline Efficacy of corporate boards & 5.4 & 4.6 & 4.1 \\
\hline Protection of minority shareholder's interests & 5.2 & 4.3 & 3.5 \\
\hline Strength of investor protection & 6.5 & 4.5 & 4.5 \\
\hline
\end{tabular}

$\left({ }^{*}\right.$ Compiled by the author based on the data of (Schwab, 2014)) 
Quality of institutional structure of the national economy in terms of priority ranking of influence on the of institutional effectiveness level for each formed cluster of countries is determined at the present stage by their significance rating for the paired correlation coefficient (Table 3) (Annex 2).

Table 3. Institutional structure quality rating grouped according to the priority ranking of the influence on the institutional economic effectiveness

\begin{tabular}{|c|c|c|}
\hline \multicolumn{3}{|l|}{ Institutional structure quality rating } \\
\hline Cluster 1 & Cluster 2 & Cluster 3 \\
\hline Intellectual property protection (Xint) & Efficacy of corporate boards & Irregular payments and bribes \\
\hline $\begin{array}{l}\text { Effectiveness of legal framework in setting disputes } \\
\text { (Xeffd) }\end{array}$ & Intellectual property protection & Business costs of terrorism \\
\hline $\begin{array}{l}\text { Effectiveness of legal framework in challenging regs } \\
\text { (Xefr) }\end{array}$ & $\begin{array}{l}\text { Effectiveness of legal framework in setting } \\
\text { disputes }\end{array}$ & Business costs of crime and violence \\
\hline Property rights (Xprop) & Ethical behavior of firms & Organized crime \\
\hline Wastefulness of government spending (Xmas) & Strength of auditing and reporting standards & Favoritism in decisions of government officials \\
\hline Reliability of police services (Xrel) & Judicial independence & $\begin{array}{l}\text { Effectiveness of legal framework in challenging } \\
\text { regs }\end{array}$ \\
\hline Diversion of public funds (Xdiv) & Protection of minority shareholder's interests & Property rights \\
\hline Transparency of government policymaking (Xtran) & Property rights & Efficacy of corporate boards \\
\hline Burden of government regulation (Xbar) & Strength of investor protection & $\begin{array}{l}\text { Effectiveness of legal framework in setting } \\
\text { disputes }\end{array}$ \\
\hline Business costs of crime and violence (Xbcv) & $\begin{array}{l}\text { Effectiveness of legal framework in challenging } \\
\text { regs }\end{array}$ & Intellectual property protection \\
\hline Public trust in politicians (Xpub) & Business costs of terrorism & Transparency of government policymaking \\
\hline Strength of auditing and reporting standards (Xstr) & Organized crime & Reliability of police services \\
\hline Organized crime (Xorg) & Business costs of crime and violence & Protection of minority shareholder's interests \\
\hline Protection of minority shareholder's interests (Xprot) & Irregular payments and bribes & Public trust in politicians \\
\hline Efficacy of corporate boards (Xjud) & Wastefulness of government spending & Judicial independence \\
\hline Strength of investor protection (Xsip) & Diversion of public funds & Strength of investor protection \\
\hline Ethical behavior of firms (Xeth) & Public trust in politicians & Ethical behavior of firms \\
\hline Irregular payments and bribes (Xirr) & Burden of government regulation & Strength of auditing and reporting standards \\
\hline Judicial independence (Xjud) & Reliability of police services & Burden of government regulation \\
\hline Business costs of terrorism (Xbust) & Transparency of government policymaking & Diversion of public funds \\
\hline Favoritism in decisions of government officials (Xfav) & Favoritism in decisions of government officials & Wastefulness of government spending \\
\hline
\end{tabular}

\section{Discussion}

The quality of institutional structure predetermines institutional effectiveness of the economy and influences the level of its development in the current context. For the purposes of reasoning and identifying the main quantitative characteristics of the institutional structure quality in terms of institutional effectiveness it is advisable to develop a model of institutional effectiveness by the clusters of countries. The basis of the model is the influence ranking of the quality of the institutional structure components.

Based on the established influence priorities of individual institutions as indicators of the institutional structure quality making impact on the effectiveness of national economies of the first cluster countries within the empirical research an institutional effectiveness model has been developed in the current context:

$Y(I E) 1=0.215754 \cdot$ Xint $+0.206425 \cdot$ Xeffd $+0.152463 \cdot$ Xefr +0.147873 .

Xprop $+0.035233 \cdot$ Xwas $+0.026423 \cdot$ Xrel $+0.023604 \cdot$ Xdiv $+0.023452 \cdot$

$X$ tran $+0.020019 \cdot X$ bar $+0.018982 \cdot X s t r+0.018750 \cdot X b c v+0.018657 \cdot$

Xpub $+0.014972 \cdot$ Xorg $+0.014247 \cdot$ Xprot $+0.012455 \cdot$ Xefb $+0.010742 \cdot$

Xsip $+0.010211 \cdot$ Xjud $+0.009898 \cdot$ Xeth $+0.009364 \cdot$ Xirr $+0.007543 \cdot$ Xbust $+0.002898 \cdot$ Xfav

The presented model of institutional economic effectiveness is developed on the basis of correlation-regression analysis. Adequacy of the developed model is proved by its statistical characteristics:

multiple correlation coefficient approaches $1(\mathrm{R}=0.89999981)$;

determination coefficient is over 0.75 ( $R 2=0.80999966)$;

the obtained value of the Fisher test exceeds the tabulated one $(F(21,95)=1.64)$.

To systematize the presented results of the model all characteristics of the institutional structure quality are grouped into four blocks according to the functional purpose: law institution quality; quality of the institution of trust in 
governmental authorities; quality of the corporate relations institution and quality of the corruption and terrorism institution.

The model of institutional economic effectiveness gives grounds to state the following. The first cluster is formed of 29 countries with a high level of development, where the GDP per capita exceeds USD 17,000. At the present stage of development the institutional efficiency of the national economy is provided by the following qualitative proportions the institutional structure: $72.25 \%$ of law institution quality; $14.74 \%$ of quality of the institution of trust in governmental authorities; $7.65 \%$ of quality of the corporate relations institution and $6 \%$ of quality of the corruption and terrorism institution.

In view of the priority ranking of the quality of the economic institutions influence on the institutional effectiveness, an institutional effectiveness model in modern conditions for the countries of the second cluster:

$Y(I E) 2=0.093323 \cdot$ Xefb $+0.073525 \cdot$ Xint $+0.070635 \cdot$ Xeffd $+0.067653 \cdot$

Xeth $+0.066788 \cdot X$ str $+0.064345 \cdot X j u d+0.063884 \cdot$ Xprot +0.062589 .

Xprop $+0.06233 \cdot$ Xsip $+0.050498 \cdot X e f r+0.047361 \cdot$ Xbust +0.039561

Xorg $+0.038673 \cdot X b c v+0.035342 \cdot X i r r+0.028676 \cdot X w a s+0.026776 \cdot$

Xdiv $+0.024639 \cdot X p u b+0.023212 \cdot$ Xbar $+0.020646 \cdot$ Xrel $+0.019856 \cdot$ Xfav $+0.019657 \cdot$ Xtran

Adequacy of the model is confirmed by its statistical characteristics:

multiple correlation coefficient approaches $1(\mathrm{R}=0.89999911)$;

determination coefficient is over $0.75(\mathrm{R} 2=0.80999840)$;

the obtained value of the Fisher test exceeds the tabulated one $F(21,191)=1.57$.

The second cluster rgroups 53 countries with the GDP per capita level over USD 3,000, but less than USD 17,000. This institutional structure provides a middle level of institutional effectiveness. This in its turn leads to significantly lower rate of the incremental growth of the economy and the welfare of the state as opposed to the first cluster.

In the current context of economic performance the institutional effectiveness is achieved by means of: $41.83 \%$ of quality of the corporate relations institution, $25.72 \%$ of quality of the law institution; $18.08 \%$ of quality of the corruption and terrorism institution; $4.36 \%$ of quality of the institution of trust in governmental authorities.

The third cluster is represented by the countries with the low level of institutional economic effectiveness. It includes 62 countries with GDP per capita not exceeding USD 3,000. Such countries are characterized by low rates growth of personal income and volatile dynamics of the country's economy development.

This institutional effectiveness model at the current stage of economic development appears as follows:

$Y(I E) 3=0.104732 \cdot$ Xirr $+0.094544 \cdot$ Xbust $+0.085235 \cdot$ Xbcv $+0.066326 \cdot$

Xorg $+0.063542 \cdot$ Xfav $+0.058776 \cdot$ Xefr $+0.050043 \cdot$ Xprop $+0.048763 \cdot$

Xefb $+0.047532 \cdot$ Xeffd $+0.041254 \cdot$ Xint $+0.040254 \cdot$ Xtran $+0.037678 \cdot$

Xrel $+0.037452 \cdot$ Xprot $+0.036457 \cdot$ Xpub $+0.036450 \cdot$ Xjud $+0.029836 \cdot$

Xsip $+0.027455 \cdot$ Xeth $+0.027434 \cdot$ Xstr $+0.024453 \cdot$ Xbar $+0.021231 \cdot$ Xdiv $+0.020594 \cdot$ Xwas

The model is adequate, which is indicated by its statistical characteristics:

multiple correlation coefficient approaches $1(\mathrm{R}=0.89999817)$;

determination coefficient is over 0.75 ( $\mathrm{R} 2=0.80999671)$;

the obtained value of the Fisher test exceeds the tabulated one $F(21,165)=1.58$.

Based on developed model it can be concluded that the institutional effectiveness predetermines the qualitative proportions of institutional structure as: $41.44 \%$ of quality of the corruption and terrorism institution; $20.74 \%$ of quality of the corporate relations institution; $19.76 \%$ of quality of the law institution and $18.07 \%$ of quality of the institution of trust in governmental authorities.

Within the third cluster Italy - a country with the developed market economy - is characterized by a low level of institutional effectiveness. This position slightly contradicts the concept of direct dependence of the economic growth and institutional economic effectiveness. As indicated by the research, in the institutional structure of the country the quality of the corruption and terrorism institution exerts the prevailing influence on the institutional economic effectiveness. The research confirmed the fact that Italy is the most corrupt country in Europe. According to the official data, its economy annually receives by 4\% of GDP less than due because of the corrupt practices (Is Italy the most corrupt country?, 2014). The paradox of the economic growth amid the low institutional effectiveness is explained by the following fact. Corruption may considerably increase the growth of economy; however it means that there is no level playing field for everybody in the country. Regulation, the basis of which is formed rather by 'bargains' than by the rules, upsets establishment of proper institutions that would promote the development. And it results in the volatile growth (Siddiqui and Masood, 2009). This economic system is less stable in the long-term prospect. 


\section{Conclusions}

1. Based on the presented models of institutional economic effectiveness it is possible to conclude that in the current context the highest level of institutional effectiveness is achieved by the quality of institutional structure in the developed countries.

2. The suggested model of institutional economic effectiveness has practical importance and allows developing a strategy of institutional transformations aimed at optimization of institutional environment as a factor providing the economic growth of any state.

3. It seems reasonable to bring the policy of institutional amendments of the countries with medium and low level of institutional effectiveness closer to these proportions of institutional economic structure quality. The quality improvement of the institution of law, providing the economic liberalization and promoting the growth of general welfare of the country should become a basis for institutional transformations of the economy.

\section{References}

Artamonov, N.V. (2010). Vvedenie v Ekonometriku. Kurs Lektsiy. [Getting Started with Econometrics. A course of lectures.] - Moscow: MGIMO, (P.204). [in Russian]

Baum, M., Lake, D. (2003). The political economy of growth: democracy and human capital, American Journal of Political Science (Vol. $47, \mathrm{~N} 2$, pp. 333-347).

Beck, T., Laeven, L. (2006). Institution building and growth in transition economies, Journal of Economic Growth (Vol. 11, pp. 157-186).

Cleaver, F. (2015). Furthering critical institutionalism, International Journal of the Commons (Vol. 9, N 1, pp. 1-18).

Coase, R. (2001). Priroda firmy. Nobelevskaya lektsiya "Institutsionalnaya priroda proizvodstva" [The Nature of Firm. Nobel Prize Lecture "Institutional Nature of Production". - Moscow: Delo, (P.462). [in Russian]

Dementiev, V.V., Nureev, R.M. (2011). Institutsionalnye problemy effektivnogo gosudarstva. [Institutional Problems of the Efficient State]. Monograph. - Donetsk: DonNTU, (P.372). [in Russian]

Fioretos, O, Falleti, T.G. (2015). The Oxford Handbook of Historical Institutionalism. Oxford University Press, forthcoming, $352 \mathrm{p}$.

Hicks, J.R. (2004). Osnovaniya ekonomiki blagosostoyaniya [The Foundations of Welfare Economics] // Vekhi Ekonomicheskoi Mysli. Vol. 4. Ekonomika blagosostoyaniya i obshchestvennyy vybor [Economy of Welfare and the Public Choice]. - Ekonomicheskaya shkola Publishing House, (pp. 17-38). [in Russian]

Inshakov, O.V. (2003). Ekonomicheskie instituty i institutsii: k voprosu o tipologii i klassifikatsii [Economic institutions and institutes: on the Issue of Typology and Classification] // Sotsis(No. 9, pp. 42-51). - Moscow [in Russian]

Italiya - samaya korrumpirovannaya strana v Evrope? [Is Italy the most corrupt country?] (2014). [in Russian] http://www.studiole galegrasso.net/ru/2014-02-I-italia-e-il-paese-piu-corrotto/

Kaldor, N. (1939). Welfare propositions of economics and interpersonal comparisons of utility // The Economic Journal (Vol. 49, N 195, pp. 549-552).

Kooij, Van der S., Zwarteveen, M., Kuper, M. (2015). The Material of the Social: the Mutual Shaping of Institutions by Irrigation Technology and Society in Seguia Khrichfa, Morocco // International Journal of the Commons (No.9 (1), pp. 129-150).

Kozyrev, V.M. (2014). Institutsionalizm vazhneyshee napravlenie sovremennoy ekonomicheskoy teorii [Institutionalism as the Most Important Prospect of Economic Theory] // Bulletin of RMAT (No.1 (10), pp. 37-52). - Khimki. [in Russian]

Kuzmenko, S.Yu. (2008). Modernizatsiya kak instrument izmeneniya ekonomicheskikh institutov [Modernization as an Instrument of Transformation of the Economic Institutions] // Bulletin of TGU (Iss.1 (69), pp. 34-47). - Tom. [in Russian]

Lane, J., Rohner, D. (2014). Institution Building and Spillovers // Swiss Political Science Review (Iss.10, No.1, pp. 77-90).

Lawson, T. (2006). The Nature of Heterodox Economics, Cambridge Journal of Economics (N 30 (4), pp. 483-505).

Marin, A., Bjorklund, I. (2015). A Tragedy of Errors? Institutional Dynamics and Land Tenure in Finnmark, Norway, International Journal of the Commons (Vol. 9, No.1, pp. 19-40).

Maskin, E.S. (2013). Mechanism Design: How to Implement Social Goals // American Economic Review (Vol. 98, Iss. 3, pp. 567-576).

North, D. (1997). Instituty, institutsionalnye izmeneniya i funktsionirovanie ekonomiki. [Institutions, Institutional Amendments and Economy Performance]. - Moscow: Foundation of economic book "Nachala", P.180. [in Russian]

Nureev, R.M. (2000). Institutsionalizm: vchera, segodnya i zavtra. Vstupitelnaya statya k "Institutsionalnaya ekonomika" [Institutionalism: yesterday, today and tomorrow.] / A foreword to Oleynik, A. Institutional Economy. Textbook - Moscow: INFRA-M, pp. 4-18. [in Russian]

Olson, M. (2000). Power and Prosperity: Outgrowing Communist and Capitalist Dictatorships. - New York: Basic books, 225 p.

Pohoaţă, I. (2015). To the Springs of a Modern Economic Theory: Institutionalism. http://anale.feaa.uaic.ro/anale/resurse/15_Pohoata_ I_-To_the_springs_of_a_modern_economic_theory-institutionalism.pdf.

Rotbard, M. (1979). The Myth of Efficiency / in Time, Uncertainty, and Disequilibrium M. Rizzo (ed.). Lexington, Massachusetts, D.C. Heath, (pp. 90-95).

Schwab K. (2014). The Global Competitiveness Report 2014-2015. World Economic Forum. Columbia, 549 p.

Shapkin, V.V. (2011). Metodologicheskie osnovaniya institutsionalizma [Methodological Foundations of Institutionalism] // Problems of Contemporary Economy (Iss. 2, pp. 58-62). - St. Petersburg [in Russian] 
Siddiqui, D., Masood, A. (2009). Institutions and Economic Growth: a Cross-Country Evidence. MPRA Paper No. 19747, Munich Personal RePEc Archive, $27 \mathrm{p}$.

Sukharev, O.S. (2009). Teoriya effektivnosti ekonomiki [Theory of Economic Effectiveness]. Monograph. Finances and Statistics, P. 368. [in Russian]

Veblen, T. (2011). The Theory of Leisure Class. - Moscow: Librokom. (P 368). [in Russian]

Volchik, V.V., Oganesyan, A.A. (2014). Zachem nuzhna staraya institutsionalnaya ekonomika esli est neoinstitutsionalizm? [What is OIE needed for, if there is NIE?] TERRA ECONOMICUS (Vol. 12, No. 4, pp. 79-90). Rostov-on-Don, [in Russian].

Williamson, E. (1992). The Economic Institutions of Capitalism: Firms, Markets, Relational Contracting. Free Press, 485 p.

World Bank Group. (2014) www.worldbank.org. Retrieved from http://www.worldbank.org/.

Yefimov, V.M. (2013). Ot mashin udovolstviya k moralnym soobshchestvam (Razmyshleniya nad novoy knigoy Dzheffri Khodzhsona) [From Machines of Pleasure to Moral Communities (Speculation on a new book by Jeffrey Hodgson)], Journal of Institutional Studies (Vol. 5, No.2, pp. 7-47). - Rostov-on-Don. [in Russian]

Zaslavskaya, T.I. (2004). Sovremennoe rossiyskoe obshchestvo: sotsialnyy mekhanizm transformatsii. [Contemporary Russian Society: Social Mechanism of Transformation]. Monograph. - Moscow: Delo. (P.400). [in Russian]

\section{ANNEX 1}

Table 1.1. Results of cluster 1 formation based on cluster analysis of institutional effectiveness of 114 countries of the world

\begin{tabular}{|lcccccc|}
\hline Country & Australia & Austria & Belgium & Canada & Chile & Denmark \\
\hline Euclidian distance & 0.506063 & 0.6320047 & 0.5756703 & 0.5709319 & 0.6334435 & 0.5465587 \\
\hline Country & Estonia & Finland & Germany & Hong Kong SAR & Iceland & Ireland \\
\hline Euclidian distance & 0.55168 & 0.7611386 & 0.4191666 & 0.6931184 & 0.5188532 & 0.5057615 \\
\hline Country & Japan & Luxembourg & Malaysia & Netherlands & New Zealand & Norway \\
\hline Euclidian distance & 0.379268 & 0.6209186 & 0.7029873 & 0.4829844 & 0.9853216 & 0.4491105 \\
\hline Country & Oman & Qatar & Rwanda & Saudi Arabia & Singapore & Sweden \\
\hline Euclidian distance & 0.591151 & 0.8787646 & 0.5521222 & 0.4957808 & 0.9411557 & 0.2432159 \\
\hline Country & Switzerland & Taiwan, China & United Arab Emirates & United Kingdom & United States & \\
\hline Euclidian distance & 0.839366 & 0.7036927 & 0.7143548 & 0.4873518 & 0.9386779 & \\
\hline
\end{tabular}

Table 1.2. Results of cluster 2 formation based on cluster analysis of institutional effectiveness of 114 countries of the world

\begin{tabular}{|lcccccc|}
\hline Country & Armenia & Azerbaijan & Bahrain & Barbados & Bhutan & Botswana \\
\hline Euclidian distance & 0.562965 & 0.534672 & 0.788193 & 0.86903 & 0.723104 & 0.478378 \\
\hline Country & Cape Verde & China & Costa Rica & Cyprus & Czech Republic & France \\
\hline Euclidian distance & 0.55654 & 0.413888 & 0.712139 & 0.510211 & 0.667888 & 0.762034 \\
\hline Country & Gambia, The & Georgia & Ghana & Greece & Hungary & India \\
\hline Euclidian distance & 0.739187 & 0.721989 & 0.557377 & 0.624096 & 0.66972 & 0.54222 \\
\hline Country & Indonesia & Israel & Jordan & Kazakhstan & Kenya & Korea, Rep. \\
\hline Euclidian distance & 0.423489 & 0.916918 & 0.738775 & 0.411945 & 0.762083 & 0.545986 \\
\hline Country & Kuwait & Lao PDR & Latvia & Lesotho & Lithuania & Macedonia, FYR \\
\hline Euclidian distance & 0.435292 & 0.97292 & 0.407735 & 0.645721 & 0.360198 & 0.470718 \\
\hline Country & Malawi & Malta & Mauritius & Montenegro & Morocco & Namibia \\
\hline Euclidian distance & 0.510274 & 0.531267 & 0.764591 & 0.386631 & 0.360882 & 0.416186 \\
\hline Country & Panama & Philippines & Poland & Puerto Rico & Senegal & Seychelles \\
\hline Euclidian distance & 0.483356 & 0.463157 & 0.492034 & 1.00985 & 0.671018 & 0.30906 \\
\hline Country & Slovenia & South Africa & Spain & Sri Lanka & Swaziland & Tajikistan \\
\hline Euclidian distance & 0.896733 & 1.225951 & 0.597395 & 0.473847 & 0.335446 & 0.572237 \\
\hline Country & Thailand & Tunisia & Turkey & Uruguay & Zambia & \\
\hline Euclidian distance & 0.809406 & 0.617675 & 0.491726 & 0.828239 & 0.332361 & \\
\hline
\end{tabular}


Table 1.3. Results of cluster 3 formation based on cluster analysis of institutional effectiveness of 114 countries of the world

\begin{tabular}{|lcccccc|}
\hline Country & Albania & Algeria & Angola & Argentina & Bangladesh & Bolivia \\
\hline Euclidian distance & 0.7180458 & 0.4224483 & 0.727953 & 0.6549801 & 0.582494 & 0.568123 \\
\hline Country & Brazil & Bulgaria & Burkina Faso & Burundi & Cambodia & Cameroon \\
\hline Euclidian distance & 0.7019963 & 0.5136542 & 0.4709163 & 0.5512232 & 0.298526 & 0.470351 \\
\hline Country & Chad & Colombia & Côte d'Ivoire & Croatia & Dominican Republic & Egypt \\
\hline Euclidian distance & 0.6969108 & 1.013916 & 0.6528895 & 0.8774725 & 0.425372 & 0.770687 \\
\hline Country & El Salvador & Ethiopia & Gabon & Guatemala & Guinea & Guyana \\
\hline Euclidian distance & 0.7099665 & 0.6460583 & 0.6691325 & 0.7640371 & 0.697372 & 0.436897 \\
\hline Country & Haiti & Honduras & Iran, Islamic Rep. & Italy & Jamaica & Kyrgyz Republic \\
\hline Euclidian distance & 0.6277515 & 0.6951152 & 0.4765936 & 0.7898865 & 0.847891 & 0.493776 \\
\hline Country & Lebanon & Libya & Madagascar & Mali & Mauritania & Mexico \\
\hline Euclidian distance & 0.7384571 & 1.139253 & 0.3283926 & 0.6807414 & 0.772451 & 0.572466 \\
\hline Country & Moldova & Mongolia & Mozambique & Myanmar & Nepal & Nicaragua \\
\hline Euclidian distance & 0.5530935 & 0.6615899 & 0.3523141 & 0.8321666 & 0.292439 & 0.423367 \\
\hline Country & Nigeria & Pakistan & Paraguay & Peru & Portugal & Romania \\
\hline Euclidian distance & 0.5889097 & 0.6726218 & 0.6086272 & 0.7117378 & 0.660211 & 0.50774 \\
\hline Country & Russian Federation & Serbia & Sierra Leone & Slovak Republic & Suriname & Tanzania \\
\hline Euclidian distance & 0.3368412 & 0.4571476 & 0.5227666 & 0.6221736 & 0.851899 & 0.400081 \\
\hline Country & Timor-Leste & Trinidad and Tobago & Uganda & Ukraine & Venezuela & Vietnam \\
\hline Euclidian distance & 0.4515639 & 0.7415587 & 0.3985665 & 0.403459 & 1.297907 & 0.567251 \\
\hline Country & Yemen & Zimbabwe & & & & \\
\hline Euclidian distance & 0.8571265 & 0.7474248 & & & & \\
\hline & & & & & \\
\end{tabular}

\section{ANNEX 2}

Table 2.1. Values of the paired correlation coefficient of institutional structure quality rating as to the level of institutional economic effectiveness

\begin{tabular}{|lccc|}
\hline Parameters of institutional structure quality & For cluster 1 & For cluster 2 & For cluster 3 \\
\hline Effectiveness of legal framework in setting disputes & 0.88 & 0.67 & 0.39 \\
\hline Effectiveness of legal framework in challenging regs & 0.65 & 0.48 & 0.49 \\
\hline Intellectual property protection & 0.92 & 0.7 & 0.34 \\
\hline Property rights & 0.63 & 0.6 & 0.42 \\
\hline Public trust in politicians & 0.08 & 0.23 & 0.3 \\
\hline Transparency of government policymaking & 0.1 & 0.19 & 0.33 \\
\hline Reliability of police services & 0.11 & 0.2 & 0.31 \\
\hline Wastefulness of government spending & 0.15 & 0.27 & 0.17 \\
\hline Burden of government regulation & 0.09 & 0.22 & 0.2 \\
\hline Diversion of public funds & 0.1 & 0.26 & 0.18 \\
\hline Judicial independence & 0.04 & 0.61 & 0.3 \\
\hline Ethical behavior of firms & 0.04 & 0.65 & 0.23 \\
\hline Strength of auditing and reporting standards & 0.08 & 0.64 & 0.23 \\
\hline Efficacy of corporate boards & 0.05 & 0.89 & 0.41 \\
\hline Protection of minority shareholder's interests & 0.06 & 0.61 & 0.31 \\
\hline Strength of investor protection & 0.05 & 0.59 & 0.25 \\
\hline Irregular payments and bribes & 0.04 & 0.34 & 0.87 \\
\hline Business costs of terrorism & 0.03 & 0.45 & 0.79 \\
\hline Favoritism in decisions of government officials & 0.01 & 0.19 & 0.53 \\
\hline Business costs of crime and violence & 0.08 & 0.37 & 0.71 \\
\hline Organized crime & 0.06 & 0.38 & 0.55 \\
\hline
\end{tabular}

( ${ }^{*}$ Compiled by the author based on the data of (Schwab, 2014)) 
ISSN 2039-2117 (online)

ISSN 2039-9340 (print)
Mediterranean Journal of Social Sciences MCSER Publishing, Rome-Italy
Vol 6 No 5 S4

October 2015 